УДК 304.3:[687.01:17.022.1]

\author{
Михайлова Рада Дмитрівна \\ доктор мистецтвознавства, професор, \\ Київський начіональний університет \\ культури і мистецтв, \\ Kü̈в, Украйна, \\ radami@rambler.ru \\ Федорова Свгенія Володимирівна \\ аспірантка, \\ Київсьжий Національний \\ університет культури і мистецтв, \\ Київ, Україна, \\ zhesichka.fedorova@gmail.com
}

\title{
ПРО ЗМІСТ І СПІВВЦДНОШЕННЯ ПОНЯТЬ «ОБРАЗ» ТА «ІМІДЖ»
}

Мета роботи. У статті досліджується зміст понять «образ» та «імідж», які поширені у сферах дизайну, індустрії моди, стилетворення, i зазвичай застосовуються як тотожні у двоїстому виразі «імідж-образ». Методологія дослідження полягає у застосуванні комплексного аналізу формулювань та визначень кожного із понять у контексті різних дисциплін, безпосередньо чи опосередковано пов'язано із зазначеним явищем. Наукова новизна роботи полягас в уточненні наукових уявлень про зміст термінів «імідж» та «образ», їх специфіки, параметрів взаємодії та співвідношень, запропоновано їхнє тлумачення в контексті дизайну та іміджелогії. Висновки. Підсумовано, що співвідношення імідж - образ існус у взаємодії внутрішнього та зовнішнього, де смислове навантаження поняття «образ» відповідае «внутрішньому стану» індивідуума, а «імідж» - його зовнішнім проявам, де імідж є різновидом образу, сформованого внаслідок сприйняття тих чи тих характеристик об'єкта; образ більше пов'язаний з психотипом та природним характером, вдачею індивідуума, що послідовно, гармонійно поєднус особисті риси у їх найвиразніших проявах. Імідж трансформує уявлення під певний «штучний» еталон. Зведені шляхом поєднання матеріальних та нематеріальних елементів, імідж та образ відображають індивідуально-особистісні та загальні закономірності розвитку культури та людини.

Ключові слова: образ, імідж, іміджелогія, стиль, індустрія моди, мистецтво, художня культура. 
Михайлова Рада Дмитриевна, доктор искусствоведения, профессор, Киевский национальньй университет культуры и искуссть. Киев, Украина

Федорова Евгения Владимировна, аспирантка Киевского Национального университета культуры и искусств. Киев, Украина

\section{О содержании и соотношении понятий «Образ» и «Имидж»}

Цель роботы. В статье исследуется содержание понятий «образ» и «имидж», которые имеют широкое использование в сферах дизайна, индустрии моды, стилеобразования, которые обычно применяют как тождественные в виде двойного выражения «имидж-образ». Методология исследования состоит в применении комплексного анализа формулировок и определений каждого понятия в контексте разных дисциплин, прямо или косвенно связанных с данным явлением. Научная новизна работы состонт в уточнении научных представлений о содержании терминов «имидж» и «образ», их специфику, параметры взаємодействия и соотношений. Предложено их толкование в контексте дизайна та имиджелогии. Выводы. Подытожено, что соотношение имиджобраз существует во взаимодействии внутреннего и внешнего, где смысловая нагрузка понятия «образ» отвечает внутреннему состоянию индивидуума, а «имидж» - его внешним проявлениям, где имидж является разновидностью образа, сформированного вследствии восприятия тех или иных характеристик объекта; образ больше связан с психотипом и природным характером, склонностями индивидуума, которые последовательно, гармонично сочетают личные черты в их наиболее выразительных проявлениях. Имидж трансформирует представления под определенный «искусственный» эталон. Сведенные путем сочетания материальных и нематериальньг элементов, имидж и образ отображают индивидуально-личностные и общин закономерности развития культуры и человека.

Ключевые слова: образ, имидж, имиджелогия, стиль, индустрия моды, искусство, художественая культура.

Mykhailova Rada, Doctor of Arts Study, professor, Kyiv National University of Culture and Arts. Kyiv, Ukraine

Fedorova Yevgeniya, graduate student, Kyiv National University of Culture and Arts. Kyiv, Ukraine

\section{About contents and correlation of concepts «character» and «image»}

Main objective of the study. Article research of maintenance of concepts «character» and «image», that have deployment in the spheres of design, industry of fashion, stilies, which usually apply as identical as double expression «imagecharacter». Research methodology consists of application of complex analysis of formulations and determinations of every concept in the context of different disciplines, 
straight or undirect related to this main. The scientific novelty of work consists of clarification of ideas about contents terms «image» and «character», their specific, parameters of interrelations and correlations. They are offered explanations in the context of design that imagology. Findings. It is summed up that the image-image relationship exists in the interaction of the internal and external, where the semantic load of the concept «image» corresponds to the internal state of the individual, and the «image» - to its external manifestations, where the image is a kind of image formed due to the perception of certain characteristics of the object; character is anymore related to psihotipe and natural character, individual inclination, that consistently, harmoniously combine the personal lines in their most expressive shows. Image transforms representations for a certain «artificial» standard. Taken by combination of material and non-material elements, an image and character represent individually-personality and communities of conformity to law of development of culture and people.

Key words: character, image, imagelogy, style, industry of fashion, art, art culture.

Ветуп. Поняття іміджу, що нині є одним з пріоритетних у середовищі дизайнерів-фахівців різних напрямів індустрії моди, традиційно розглядають у контексті явища стилю. Так, зокрема, його подає український практикмодельср I. Гардабхадзе в лекційному курсі, присвяченому основам стилю та іміджу, спираючись на низку джерел [1]. Уніфіковане уявлення про те, що імідж виникає як результат враження, що за лічені секунди формує уявлення про людський образ як віддзеркалення соціального та психофізичного типу, станової та професійної приналежності, вікової групи, статків, схильностей, характеру, інтересів фіксує колективне інтернет видання, присвячене вимогам до сучасного дрес-коду, позначеного рисами свідомо обраного іміджу [2]. Згідно з тотальною соціологізацісю суспільства, пов'язуючи цей аспект із напрацюваннями психології, А. Панасюк пропонує розподіл іміджу на типи, де основними зазначає корпоративний - «імідж фірми» (компанії, закладу, установи, політичної партії, громадської організації) та «індивідуальний» (керівника, бізнесмена, політика, артиста, лідера руху) [3]. На імідж та образ у контексті молодіжних субкультур та реклами звертас увагу С. Пархоменко, підкресливши різницю між даними поняттями, хоча не ставила питання про їх детальний розгляд [21, с. 138-139]. Попри те, що до поняття іміджу звертається чимало фахівців, провідним залишається практичний аспект, тобто з'ясування механізмів його створення, в той час, як теоретичний - конкретизація змісту, залишається недостатньо з'ясованою, про що саме свідчить використання двоїстого виразу «імідж-образ». Мета статті - проаналізувати терміни «імідж» й «образ» та виявити їнғо сутність, параметри взаємодії та співвідношень. 
Поєднання понять «імідж» та «образ» у єдине ціле, за загально прийнятими уявленнями, утворено внаслідок запозичення з англійської мови та мають етимологічну спільність (23, с. 139). Насправді, слово «image» в англійській мові, як свідчать словники, має кілька значень: це - «образ як картинка», «образ-зображення», «образ-відображення». Відтак, імідж та образ не $є$ синонімами і не можуть заміняти один одного.

До дизайнерських практик обидва поняття потрапили 3 літературознавства, причому «імідж» породив дисципліну іміджелогію (імагологія), яка стала вивчати механізми створення іміджу [5]. У сучасних умовах імідж є також предметом вивчення культурології, в якій йому відведено окремий розділ [4, с. 28-129]. Імагологія (від лат. imago - зображення) розглядає закони створення, функціонування та інтерпретування образів, образи в різних контекстах, зокрема, можливості їхньої передачі з одного наукового «середо-вища» до іншого, а також функціонування в «інших», чужорідних середовищах [4]. Міждисциплінарна за характером, імагологія аналізуе дані, отримані $з$ різних джерел, на основі яких виявляються внутрішньо усвідомлені загальні для різних реципіснтів уявлення про зовнішні об'єкти.

Назву «іміджелогія» використовують також соціологія й психологія. Перша вивчає імідж як штучно сконструйований образ, інша розвиває тему іміджу у дисциплінарному розділі «імагогіка», який вивчає різні впливи на формування поняття «образ» [6]. Психологія підходить до питання образу як явища, сформованого в евідомості людини у вигляді ментальних відбитків об'єкту внаслідок сприйняття з середовища, що його оточує [8]. У значенні терміну «image» увага 3 акцентована на образ об’єку, який відтворюються у людській пеихіці на основі його характеристик, внаслідок чого образ-об'єкт розширюсться як з боку видимих зовнішніх характеристик, так і невидимих, ідеальних. Для психології інтерес представляє також категорія «образ тіла» [9].

Певний інтерес до поняття «імідж» належить також новітнім дисциплінам, наприклад, інформатиці. У вивченні інформаційних систем ця наука користується поняттям «образ», який розглядає як відтворення об’ єкту, інформацію про нього та його структуру, хоча сам опис передбачає відхилення від цілковитої тотожності. На загал математичні науки оперують поняттям «образ», який передбачає результат відображення праобразу для завданих до відображення функцій, записаних у вигляді формули. У комп'ютерних технологіях поняття «образ диску» розглядають як повну копію змісту та структури файлової системи, «образ оптичного диску» означає його повну інформацію та структуру, а «образ ПЗП» (англ. ROM image) - файл копії даних мікросхеми ігрової приставки, комп'ютера, ігрового автомату [10]. 
Спектр тлумачень заявлених понять розширюе філософія, де, зокрема, поняття «образ» застосовують для означення порядку, способу, методу, організації [11, с. 82]. Наприклад, вираз «спосіб життя» розкриває зміст, відповідний презентації, відображенню, уявленню, який передбачає сталі форми індивідуальної та групової життсдіяльності людини: особливості спілкування, поведінки, способу мислення; власне «образ» несе в собі значення «результату відображення світу в свідомості людини (відчуття, уявлення, поняття, ідеї) [7, c. 77]. Образ думок передбачає й образ світогляду, світоспоглядання, світобачення, тобто погляд на речі як погляд на життя. Відтак образ, тобто вигляд є наявне, «живе» уявлення про щось.

Чільне місце образ посідає в гуманітарних науках, де поняття художнього образу - це всезагальна категорія художньої творчості й форма тлумачення та освосння світу з позицій мистецького ідеалу, типізації, творчого перетворення дійсності. У художній літературі образ - це узагальнення у вигляді конкретизованого відтворення дійсності, зазвичай, інднвідуального явища. У художньому творі - це тип, характер як, наприклад, Дон-Кіхот в одноіменнорму творі М. Сервантеса, доктор Фауст у І. В. Гете, ін. [11]. У театральному та кіномистецтві він створюється синтезом режисури та акторського мистецтва на сцені або в кадрі як сценічний образ [12, с. 906]; в образотворочому мистецтві - це візуальне, зорове зображення, яке реалізусться притаманними живопису, скульптурі або графіці засобами у певних тематично-смислових параметрах якот, образ природи, образ смерті, абстрактний образ тощо [13]. Тлумачення художнього образу включас специфіку характеру, світогляду митця, його уявлення про красу, його життевий досвід, психологічний стан, бажання, виражені через зовнішні прояви: вчинки, рухи, голос, мову, предмети. Як базове, основоположне мистецьке поняття, мета художнього образу - типізація, узагальнення, «об’єктність», у напрямку відтворення власної поліморфної природи та змістовної вичерпності.

На відміну від образу, імідж, який поєднує реальні риси об'єкта та неіснуючі, вигадані, надумані якості створюється піаром, пропагандою, рекламою [14]. Слово імідж однокореневе зі словом «імітувати» й має таке визначення: 1) точне наслідування кого-небудь, відтворення чого-небудь; 2) уподібнення до когось чи чогось; 3) у музиці - повторення теми або мотиву в іншому голосі твору на певний інтервал вище або нижче [15]. Його мета формування в масовій свідомості певного відношення до об'єкту [16]. Поняття «імідж» включає сукупність уявлень, сформованих у громадській думці про те, як має виглядати, думати та поводитися людина у відповідності до свого статусу, як мають тї права та обов'язки в даному статусі. Зокрема, літературна предтеча іміджу, поетична течія «імажинізм» (від французького - «уявляти», 
«відчувати»), що з'явилися в Росії у др. пол. 10-х рр. ХХ ст. під впливом французької культури, ставила на перше місце саме штучні образи - метафори, побудовані на суб'сктивних, далеких від життя асоціаціях, формалістичних прийомах [17].

Внутрішня структура іміджу відповідає психологічному поняттю «Яконцепції, що є системою уявлень людини про себе, де у межах цілісної єдності існують Я-фізичне як схема власного тіла; Я-соціальне, співвідносне із сферами соціальної інтеграції: статевої, етнічної, громадянської, рольової; Яекзістенціальне як оцінка себе в аспекті життя та смерті. Формування Яконцепції людини відбувається за умовами накопичення досвіду вирішення життєвих завдань при оцінюванні ї з боку інших, де внутрішня структура іміджа утримус кілька складових. Дослідження системи «імідж-образ» як взасмодії внутрішнього та зовнішнього, демонструс уявлення людини про себе, свою зовнішність, фізичні властивості, самопочуття, нахили, потреби, визначені у вигідному для неї становищі. Однак внутрішня структура імідж-образу, яка розгортається у психологічному понятті «Я-концепції» (в уявленні людини про себе у межах цілісної єдності), у так званому «внутрішньому дзеркалі» (уявленнях людини про те, що думають про неї інші) й так званому «зовнішньому дзеркалі» (зворотному зв'язку у вигляді компліментів, критики, відвертих зізнань, назвиськ, жартівливих висловлювань, інтимних зізнань, дифірамбів), створює ситуації, коли уявлення про себе можуть не співпадати iз «внутрішнім» та «зовнішнім дзеркалом». Внутрішні якості та протиріччя так чи інакше відображаються у зовнішності людини, іiі фізіологічних особливостях, одязі, предметах, а також людському оточенні.

Отже, імідж конструюють у чіткій відповідності до конкретних вимог або завдань. Імідж «свого хлопця», «бізнес-леді», «депутата», «боса», «дружини боса» та ін., передбачає не лише наявність характерних рис зовнішнього вигляду, одягу, зачіски, а й певне відношення до життя, до себе, охоплюючи особливості поведінки, самовияв тощо. Створення іміджу відбувається із розрахунку на когось чи на щось, коли за допомогою зовнішніх проявів хочуть досягти уявного, справити враження на певне коло людей. Нині таким, наприклад, є модний імідж мачо, супермена, борця за справедливість, просто кумира молоді, які увійшли в побут як наслідування образів певних особистостей. Серед них - музиканта Елвіса Преслі, учасників групи «Бітлз», Майкла Джексона, Фреді Меркюрі, кіногероїв та кіноперсонажів Арнолльда Шварценегера, Брюса Лі, Лжекі Чана, Чака Норіса, Антоніо Бандераса, Джорджа Клуні, Мела Гібсона, Брюса Уілліса. На основі багатьох прикладів - зовнішні прояви іміджа «переважають» над внутрішнім образом, попри те, що людина демонструс назовні. Вони сприймаються оточуючими підсвідомо й формують уявлення про життєві цінності, зокрема, світоглядно-орієнтаційні, наприклад, про добро та зло. 
В індустрії моди для створенні іміджу важлива реакція на зовнішній вигляд, вбрання та зачіску, яку нині визначають як сферу габітарного іміджу. Він випливає $з$ конструйованого уявлення про певну особу поряд із кінетичним іміджем (реакцієя на поставу, рух, жести, міміку, ходу, звичні пози, розташування тіла у просторі), вербальним (який утворюсться аудіальним іміджем - як людина розмовляє, який у неї тембр, висота голосу, інтонації, дикція; мовним іміджем що людина говорить, чи логічно, точно, багатослівно, емоційно), середовищним (включає простір існування конкретної людини (житло, машина, кабінет, місце роботи, друзі, клуб, місця проведення відпуски), а також людський фактор (родина, друзі, співробітники, відпустка) [18].

Фактично будь-який об'єкт «світу», з яким людина мас зв'язок є формотворчим фактором іміджу. У цьому поняття «імідж» близьке поняттю «реноме», тобто опредмеченому іміджу, який включає все, що було «створене» конкретною особою: написані вірші, спечений торт, затверджена візитівка, що мають вияв особи з певним мисленням, рисами характеру, ставленням до світу, ін. Імідж ментальний (комунікативний та власне ментальний) передбачає спілкування в межах етикету (комунікативний), а все, що озвучено вголос або продемонстроване як уявлення про себе (ментальний), тобто: член організації Грінпіс не буде носити шапку чи комір з натурального хутра (що є, зокрема, частиною габітарного іміджу). Отже, частини зовнішнього та внутрішнього іміджу невід'ємні, знаходяться в тісній взаємозалежності і мають цілісну картину, яка впливає на сприйняття людини.

Імідж об'скта передбачас наявність думки раціонального або емоцінйого характеру про нього як про систему, предмет, людину, що виникає у психіці групи людей на основі образу, сформованого в результаті сприйняття ними тих чи інших характеристик даного об’єкту. Наприклад, діловой імідж фірми полягає у вираженні за допомогою низки засобів ії інтересів, особливостей діяльності, внутрішніх та зовнішніх якостей. Або імідж представника певної субкультури, тобто культури означеної певним соціальним середовищем, яка виникає на основі системи переконань, цінностей та норм у певний історичний час, що іх поділяе й активно використовує група людей (меншість) у межах певної культури, наприклад, молодіжної чи-то релігійних сект [19].

На такій основі явище, яке характеризують як особистий імідж, має важливий сенс та поширення серед відомих громадських, політичних діячів, представників мистецького середовища, шоу-бізнесу. До нього активно звертаються президенти країн, громадські діячі, культурні діячі, голлівудські зірки, рок-музиканти, співаки, художники. Зважаючи на те, що у шоу-бізнесі, зокрема, в музичній культурі шоу-зірки робили характерні перевтілення неодноразово, можна стверджувати, що імідж - явище змінне, воно підлягає 
модним тенденціям і має здатність до трансформацій. Так, знаменитий співак Елвіс Преслі, на початку свосї кар'сри мав прізвисько Хіллбіллі-кет, традиційне для співця кантрі та імідж «дикого», «сердитого», чесного хлопця. Під кінець музичної кар'єри, коли його проголосили королем рок-н-рола, його імідж став іншим. Він посднав королівську розкіш з рисами мачо, ковбоя, тореро [20]. «Ранній» бой» $€$ екзотичним юнаком зі Сходу 3 рисами американського плейбоя. У 1980 р. він зазнав перевтілень, які поєднували риси античного героя та іронічного лицедія. Імідж Майкла Джексона спочатку був у стилі простого хлопця 3 американських хащів, а вже на вершині слави - співак використав образ казкового «маленького принца», що дивовижним чином поєднував також риси кіногероя Чарлі Чапліна. Імідж російського співака Гарика Сукачьова поєднує риси бешкетника пролетарія й старого солдата, який «не знає слів лпобові».

Однією з найважливіших ділянок іміджевих побудувань $є$ політична сфера, до якого відносять й імідж політичного діяча, й імідж держави. Основними рисами такого іміджу вважаються дієвість, емоційне забарвлення, конкретні характеристики, перцепитивні якості об'скта, що мас соціальну значимість для тих, хто його сприймає. У цій ділянці він дихотомно постає як внутрішній імідж - для громадян, та зовнішній - для світової спільноти. Категорія «імідж держави» посднус також такі релевантні категорії іміджу: «імідж чоловіка», «імідж жінки», «імідж молоді», «імідж дитини» «імідж людей похилого віку», «імідж представника конкретної національності, етносу», де кожна категорія відображас характеристики внутрішнього й зовнішнього іміджу держави. Усі компоненти та складові цієї категорії перебувають у тісній взаємодії й динаміці, що разом постійно змінюються. Попри те, що образ держави, його репутація дуже часто базусться на елементах міфу, узагальнених стереотипах, їх значення в політиці досить вагоме. Мислення стереотипами та кліше дає змогу витрачати менше зусиль для сприйняття оточуючого середовища, спрощують процес пізнання [16, с. 367-377].

Відтак, імідж тяжіє до суб'єктивізації, адже його прообразом є не будьяке явище, а суб'єкт, «предметність». Імідж - уявлення, яке формується в суспільній або індивідуальній свідомості засобами масової комунікації та психологічного впливу. Імідж, створюється 3 метою формування в масовій свідомості певного ставлення до об'єкту. Він може поєднувати як реальні властивості об'єкта, так і приписувані йому свідомо. У самій своїй суті імідж це рекламний, представницький образ кого-небудь (напр., громадського діяча), що створюється для загалу й передбачає можливість змінити його за потреби, або підкорегувати. Імідж - це жива система, здатна до постійного розвитку еволюції та трансформації. 
Підсумовуючи, зазначимо, що співвідношення імідж - образ існує у взасмодії внутрішнього та зовнішнього, де смислове навантаження поняття «образ» відповідає «внутріпньому» стану індивідуума, а «імідж» - його зовнішнім проявам. Зважаючи на те, що поняття «образ» не $е$ повним синонімом терміна «імідж», правильним буде визначити імідж як різновид образу, а саме такий образ, прообразом якого $є$ не будь-яке явище, а суб'єкт. Імідж об’єкта - це думка раціонального або емоціонального характеру про об'скт (людину, предмет, систему), що виникла в психіці групи людей на підставі образу, сформованого внаслідок сприйняття ними тих чи тих характеристик об'єкта. Імідж більш поверхневий, багатоликий та змінний у своїх проявах, як такий, що відповідає новим тенденціям моди, змінюсться відповідно вимогам конкретного історичного моменту. Він може перетворюватися в межахах одного образу шляхом трансформацій, тобто швидкої зміни рис, або, навіть всього типажу разом. Образ, насмперед, тяжіє до поняття особистості. Він більше пов'язаний з психотипом та природним характером, вдачею індивідууму. Образ змінюеться еволюційним шляхом - шляхом накопичення та якісних змін, коли певні риси не зникають, а набувають більшої виразності за рахунок їхнього ствердження, посилення, зміцнення. Створення образу потребує тривалого часу, він підгримується внутрішнім розвитком, певними свідомими зусиллями, матеріальними накопиченнями. Образ послідовно, гармонійно поєднує особисті риси в їх найвиразніших проявах. У цілому, зведені пляхом поєднання матеріальних та нематеріальних елементів, імідж та образ узагальнено відображають індивідуально-особистісні та загальні закономірності розвитку культури й людини.

\section{Список використаних джере.}

1. Андреева Г. М. Социальная психология / Г. М. Андреева. - Москва : Аспект-Пресс, 2007. - 369 с.

2. Безклубенко С. Д. Мистецтво: терміни і поняття: енциклопедичне видання. у 2-х т. Т. 2. М-Я / С. Д. Безклубенко. - Київ : Ін-т культурології НАМ України, 2010.

3. Борев Ю. Б. Эстетика : учеб. / Ю. Б. Борев. - Москва : Высшая школа, 2002. $-511 \mathrm{c}$.

4. Гардабхадзе I. А. Основы стиля и имиджа : конспект лекций для студентов-иностранцев / І. А. Гардабхадзе. - Київ : КНУТД, 2004. - 70 с.

5. Демин Г. С. Художественный образ в живописи / Г. С. Демин [Электронный ресурс] // Вестник Тюменского государственного университета. Социально-экономические и правовые исследования. - 2011. - № 10. - 
Режим доступа : http://cyberleninka.ru/article/n/hudozhestvennyy-obraz-v-zhivopisi\# ixzz4cQtVIjZd. - Загл. с экрана.

6. Дизайн. Словник-довідник / Ін-т проблем сучасного мистецтва НАМ України ; за ред. М. І. Яковлева. - Київ : Фенікс, 2010. - С. 159.

7. Дресс-код: стиль одежды деловой женщины [Електронний ресурс]. Режим доступа : http://www.ladyboss.com.ua/style/osen-2010-code/. - Загл. с экрана.

8. Елвис Пресли [Електронний ресурс] - Режим доступа http://www.uznayvse.ru/znamenitosti/biografiya-elvis-presli.html. - Загл. с экрана.

9. Когаловский М. Р. Энциклопедия технологий баз данных / М. Р. Когаловский. - Москва : Финансы и статистика, 2002. -800 с.

10. Кошелева Ю. П. Образ в психологи: теория и практика // Вестник Московского лингвистического университета. - Москва, 2012. - № 7. - С. 115119.

11. Метаева В. Габитарный имидж лидера [Електронний ресурс] / В. Метаева - Режим доступа : http://www.bkworld.ru/archive/y2007/n042007/n04-2007_300.html._Загл. с экрана.

12. Милославская С. К. Русский язык как иностранный в истории становления европейского образа России / С. К. Милославская. - Москва Флинта-Наука, 2012. - $400 \mathrm{c}$.

13. Панасюк А. Ю. Формирование имиджа. Стратегия, психология, психотехники / А. Ю. Панасюк. - Москва : Омега-Ленинград; 2008. - 266 с.

14. Папилова Е. В. Имагология как гуманитарная дисциплина // Вестник МГУ им. М. А. Шолохова. Серия. Филологические науки. - Москва, 2011. № 4. - C. 31-40.

15. Пархоменко С. А. Субкультурні іміджі молоді в рекламі / С. А. Пархоменко // Українська культура: минуле, сучасне, шляхи розвитку: зб. наук. пр. : наук. зап. Рівненського державного гуманітарного університету : у 2 т. - Рівне: РДГУ, 2011. - Т. 2. - Вип. 17. - С.138-142.

16. Политическая имиджелогия / Под ред. А. А. Деркача, Е. Б. Перелігиной [и др.]. - Москва : Аспект-Пресс, 2006. -398 с.

17. Словник української мови. В 11 т. Т. 9. / АН УРСР, Ін-т мовознав. ім. О. О. Потебні ; за ред. І. К. Білодіда. - Київ : Наук. думка, 1980. - 699 с.

18. Тлумачний словник сучасної української мови / За ред. проф. В. С. Калашника. - Харків : Белкар-кенига, Еспада, 2005. - С. 276.

19. Щербакова А. И. Эволюция эстетической мысли России первой половины XIX века / А. И. Щербакова // Культура. Духовность. Общество. 2014. - № 13. - C. 93-98.

20. Debra L. Gimlin. Body Work: Beauty and Self Image in American Culture / Debra L. Gimlin. - Culture University of California Press, 2002. - 210 p. 


\section{References}

1. Andreeva, G. M. (2007). Social Psychology. Moscow: Aspekt-Press.

2. Bezklubenko, S.D. (2010), Art: terms and concepts: An Encyclopedic edition, vol. 2. Kiev: Instytut kulturolohii NAM Ukrainy.

3. Bilodida, I.K. (ed.) (1980). Dictionary of Ukrainian language. In 11 vol., vol. 9. Kiev: Naukova dumka.

4. Borev, Ju.B. (2002). Aesthetics: a textbook. Moscow: Vysshaya shkola.

5. Debra L. Gimlin. (2002). Body Work: Beauty and Self Image in American, Culture University of California Press, California.

6. Demin, G.S. (2011). Artistic image in painting. Available at: $<$ http://cyberleninka.ru/article/n/hudozhestvennyy-obraz-vzhivopisi\#ixzz4cQtVIjZd>.

7. Derkach, A.A. (ed.) (2006). Political image, Aspekt-Press, Moscow, 398 p.

8. Dress code: business woman's dress style. Available at: $<\mathrm{http}: / / \mathrm{www}$.lady boss.com.ua/style/osen-2010-code/>. [Accessed September 9 ${ }^{\text {th }}$ 2017].

9. Elvis Prestly. Available at: <http://www.uznayvse.ru/znamenitosti/bio grafiya-elvis-presli.html>.

10. Gardabkhadze, I.A. (2004). Basics of style and image: Lecture notes for foreign students. Kiev: Kiev National University of Technology and Design.

11. Kalashnyk, V.S. (ed.) (2005), Dictionary of modern Ukrainian language, Kharkov: Belkar-kenyha.

12. Kogalovskii, M.R. (2002). Encyclopedia of Database Technologies. Moscow: Finansy i statistika.

13. Kosheleva, Ju.P. (2012). The image of psychologists: theory and practice, Vestnik Moskovskogo lingvisticheskogo universiteta [Bulletin of the Moscow Linguistic University], no. 7, pp. 115-119.

14. Metaeva V. Habitimage of the leader. Available at: <http://www.bkworld. ru/archive/y2007/n04-2007/n04-2007_300.html.>

15. Miloslavskaia, S.K. (2012). Russian as a foreign language in the history of the emergence of the European image of Russia. Moscow: Flinta-Nauka.

16. Panasjuk, A.Ju. (2008). Formation of image. Strategy, psychology, psychotechnics. Moscow: Omega-Leningrad.

17. Papilova, E.V. (2011). Imagology as a humanitarian discipline. Vestnik MGU im. M. A. Sholokhova. Seriia. Filologicheskie nauki [Bulletin of the Moscow State University. M. A. Sholokhov. Series. Philological Sciences], no. 4, pp. 31-40.

18. Parkchomenko, S.A. (2011).Subcultural youth in advertising, Ukrainska kultura: mynule, suchasne, shliakhy rozvytku: naukovi zapysky Rivnenskoho derzhav- 
noho humanitamoho universytetu [U/krainian culture: past, present, ways of development: scientific notes of Rivne State Humanitarian University], vol. 2, issue 17 ,pp. $138-142$.

19. Shherbakova, A.I. (2014). "Evolution of the aesthetic thought of Russia in the first half of the nineteenth century", Kultura. Dukhovnost. Obshchestivo R Culiure. Spirituality: Society], no.13, pp. 93-98.

20. Yakovleva, M.I. (ed.) (2010). Design. Glossary Directory, Feniks, Kiev.

(C) Михайлова P. Д., 2016

(C) Фeдорова Є. B., 2016 